\title{
The efficacy of two different doses of vaginal isosorbide mononitrate in pre induction cervical ripening: a double blind randomised controlled trial
}

R S Vidanagamage ${ }^{1}$, I M R Goonewardene ${ }^{2}$

(Index words: cervical ripening, induction of labour, isosorbide mono nitrate)

\begin{abstract}
Objective Nitric oxide donors have been shown to cause cervical ripening. The aim of this study was to evaluate the effects on the mother and the fetus when isosorbide mononitrate (ISMN) $40 \mathrm{mg}$ or the sustained release ISMN (ISMN - SR) $60 \mathrm{mg}$ was administered vaginally for preinduction cervical ripening.
\end{abstract}

Methods A double blind randomised controlled trial. Consecutive women $(n=156)$ with uncomplicated singleton pregnancies between 40 weeks +5 days and 41 weeks' gestation with modified Bishop Scores (MBS) $<5$ were allocated by stratified (primp / multip) block randomisation to receive ISMN $40 \mathrm{mg}$, ISMN - SR $60 \mathrm{mg}$ or the placebo vitamin C $100 \mathrm{mg}$ vaginally.

Results At the commencement of the study the parity and mean age, MBS, pulse rate (PR), systolic and diastolic blood pressure (SBP and DBP), umbilical artery resistance index $(\mathrm{RI})$ and pulsatility index $(\mathrm{PI})$ were similar among the three treatment groups. There was significant increase $(p<0.001)$ of mean MBS by $1.3(95 \% \mathrm{Cl} 0.8,1.7)$ in primips and by $1.7(95 \% \mathrm{Cl} 1.3,2.0)$ in multips at 6 hours and by $2.4(95 \% \mathrm{Cl} 1.9,2.7)$ in primips and by 2.3 $(95 \% \mathrm{Cl} 2.0,2.6)$ in multips at 48 hours. Greater proportions of primips (42\% with ISMN - SR $60 \mathrm{mg}$ and $31 \%$ with ISMN $40 \mathrm{mg}, p<0.05$ ) were favourable for induction of labour (IOL) after 48 hours in comparison with the controls $(7.6 \%)$. Greater proportions of multips (46\% with ISMN - SR $60 \mathrm{mg}$ and $40 \%$ with ISMN $40 \mathrm{mg}$, $p<0.05)$ were favourable for IOL after 48 hours in comparison with the controls $(16 \%)$. A mean increase of PR by $6.7-10.2$ bpm $(95 \% \mathrm{CI} 5.0-12.5, p<0.001)$ in both ISMN groups at 180 minutes persisted up to 360 minutes. A mean reduction of SBP by $7.3-10 \mathrm{mmHg}(95 \% \mathrm{Cl}=$ $8.0-11.5, p<0.001)$ in both ISMN groups at 180 minutes persisted up to 360 mins. No significant change was seen in DBP, RI or PI. Frequency of maternal side effects (mainly headache) were higher in ISMN groups.

Conclusions When compared with the placebo Vitamin C $100 \mathrm{mg}$, vaginal ISMN $40 \mathrm{mg}$ and ISMN - SR $60 \mathrm{mg}$ lead to significantly greater cervical ripening after 6 hours and 48 hours respectively. Therefore vaginal ISMN leads to more women becoming favourable for IOL. Vaginal ISMN does not affect placental blood flow but causes headaches and clinically insignificant maternal haemodynamic changes.

Ceylon Medical Journal 2011; 56: 91-100

\section{Introduction}

In Sri Lanka, induction of labour (IOL) is commonly carried out if spontaneous labour is not established at 41 weeks' gestation. However, at 41 weeks' gestation, the cervix is unfavourable for IOL in a large number of women. IOL in the presence of an unfavourable cervix is associated with failed induction, failure to progress in labour, and an increased risk of chorioamnionitis and caesarean section (CS).

An ideal ripening agent should make the cervix soft, compliant and partially dilated without stimulating uterine contractions and have no clinically significant side effects in the mother or her baby. The methods commonly used to achieve pre induction cervical ripening at term are sweeping of membranes, intra cervical catheters including Foley catheter intra cervical and vaginal prostaglandins (PGE2), and vaginal and oral misoprostol [1-7]. Although prostaglandins are frequently used, they are associated with several adverse effects such as gastrointestinal symptoms and hyperpyrexia, as well as a high incidence of uterine hyper stimulation, acute fetal distress and rarely even uterine rupture [4-8].

Nitric oxide (NO), a free radical gas with a short half life, is considered to be a fundamental mediator of cervical ripening $[9,10]$. Cervical ripening is thought to be brought about by the interaction of $\mathrm{NO}$ and several other inflammatory cytokines which are produced in the cervix $[11,12]$. NO donors cause the release of NO in vivo. In the prophylactic management of angina pectoris, the NO donor isosorbide mononitrate (ISMN) is usually used in a dose ranging from $20-120 \mathrm{mg}$ in divided doses or 40-120 $\mathrm{mg}$ once daily as a sustained release form [13]. The

\footnotetext{
${ }^{1}$ University Obstetrics and Gynaecology Unit, Teaching Hosptial, Galle, Sri Lanka, ${ }^{2}$ Department of Obstetrics and Gynaecology, Faculty of Medicine, University of Ruhuna, Galle, Sri Lanka.
}

Correspondence: IMRG, e-mail: <malikg@eureka.lk>. Received 27 August 2010 and revised version accepted 15 March 2011. Competing interests: none declared. 
contraindications for the use of ISMN include a history of hypersensitivity or idiosyncratic response to nitrates, presence of marked anaemia, severe hypotension and hypovolaemia [13]. When given orally, the onset of action of ISMN $40 \mathrm{mg}$ is about 45 minutes, peak levels are achieved within 2 hours and it has a duration of action of about 6 to 7 hours. ISMN-SR $60 \mathrm{mg}$ has a longer duration of action of about 12 hours [14, 15]. Vaginal administration of ISMN has been shown to result in lower plasma levels with peak levels being achieved only after 6 hours or more [14]. However, vaginal ISMN is thought to have its effects on the cervix much earlier due to the direct transport of the ISMN from the vagina to the cervix $[14,16,17]$.

Although the mechanism of action in the process of cervical ripening is unclear, vaginally administered NO donors have been shown to be effective for preinduction cervical ripening at term $[7,18]$. The maternal and fetal haemodynamic changes occurring after vaginal administration of ISMN for pre-induction cervical ripening at term, have not been found to be clinically significant $[4,17,19]$.

The common side effects of ISMN viz headache, sinus tachycardia and hypotension are less severe than the side effects associated with $\mathrm{PGE}_{2}$. In Sri Lanka PGE 2 is not freely available in the government health sector and misoprostol is not registered for use as a pre-induction cervical ripening agent. Furthermore, vaginal $\mathrm{PGE}_{2}$ is more expensive (US\$ 8) compared to ISMN tablets (US\$ 0.1).

In a previous study we have shown that ISMN - SR $60 \mathrm{mg}$ was a safe, cheap and effective option for preinduction cervical ripening at 41 weeks' gestation in situations where $\mathrm{PGE}_{2}$ and misoprostol are not available [18]. The only side effect was maternal headache, which easily responded to simple analgesics.

However, ISMN is a preparation designed for oral therapy. It is possible that an ISMN specially formulated for vaginal use may have even better results. The use of vaginal ISMN for cervical ripening has the added advantage that, unlike prostaglandins, it does not stimulate uterine contractions. Therefore it can be safely used in grand multiparous women as well as women with uterine scars and even in an outpatient setting. Although prostaglandins are more effective than ISMN, outpatient use of prostaglandins carries a high risk and is not recommended. Recent studies have demonstrated that ISMN could be safely self administered by women on an outpatient basis [20,21]. The women who participated in these studies had greater maternal satisfaction and were very positive about the opportunity to undertake cervical ripening at home. Although these studies were conducted in the UK, the results are of great relevance to non industrialised countries with poor resources and limited availability of prostaglandins like Sri Lanka. The use of outpatient ISMN for cervical ripening could result in a shorter hospital stay and decreased costs to the health services.
The optimal dose of vaginal ISMN for pre-induction cervical ripening has not been established. The objectives of our current study were:

a) to compare the effects of vaginally administered ISMN $40 \mathrm{mg}$, ISMN - SR $60 \mathrm{mg}$, and the placebo Vitamin C $100 \mathrm{mg}$ in ripening the cervix and making it favourable for IOL,

b) to compare the effects of these three interventions on the cardiovascular system of the mother and the fetus,

c) to compare the systemic side effects of these three interventions on the mother,

d) to compare the outcome in the women who had IOL following the three interventions.

\section{Methods}

This double blind randomised controlled trial was conducted between March 2006 and April 2007 at the University Obstetric Unit, Teaching Hospital Mahamodara, Galle, Sri Lanka. Approval was obtained from the Ethical Review Committee, Faculty of Medicine, Galle and the trial was registered in the Sri Lanka Clinical Trials Registry.

According to studies previously carried out in the unit, it was estimated that approximately $20 \%$ of women between 40 weeks +5 days and 41 weeks' gestation will either establish spontaneous labour or become favourable for IOL within the next 48 hours. In order to detect an increase of this percentage by a further $25 \%$ after treatment with ISMN, with a power of $80 \%$ (Type II error of $20 \%$ ) and a confidence level of $95 \%$ (Type I error of 5\%) the total sample size was calculated to be 156 .

Therefore 156 consecutive women with uncomplicated singleton pregnancies with cephalic presentations, and between 40 weeks +5 days and 41 weeks' gestation, where the dates had been confirmed by an early ultrasound scan, and having a cervix unfavourable for IOL with a modified Bishop Score (MBS) $<5$ were recruited for the study [22]. Women with any medical or obstetric problems and any contraindications for the use of ISMN were excluded.

Informed written consent was obtained from all the women who were recruited. None declined to participate. The women were randomly allocated to three groups using stratified (primigravidae and multigravidae) block randomisation. Sequentially numbered sealed opaque envelopes were prepared with either a ISMN - SR $60 \mathrm{mg}$ tablet or two ISMN $20 \mathrm{mg}$ tablets (both from Micro Laboratories, Bangalore India) or a vitamin C $100 \mathrm{mg}$ tablet (placebo) by the second author and kept in a secure place in the obstetrics ward. Maternal pulse rate (PR) systolic and diastolic blood pressure (SBP and DBP) a 10 minute cardiotocogram (CTG), umbilical artery resistance index (RI), pulsatility index (PI), and the modified Bishop Scores were recorded initially by the first investigator. If the $\mathrm{CTG}$ 
Double blind randomised controlled trial. $n=156$, uncomplicated, singleton pregnancies between 40 weeks +5 days and 41 weeks gestation, modified Bishop Score $<5$

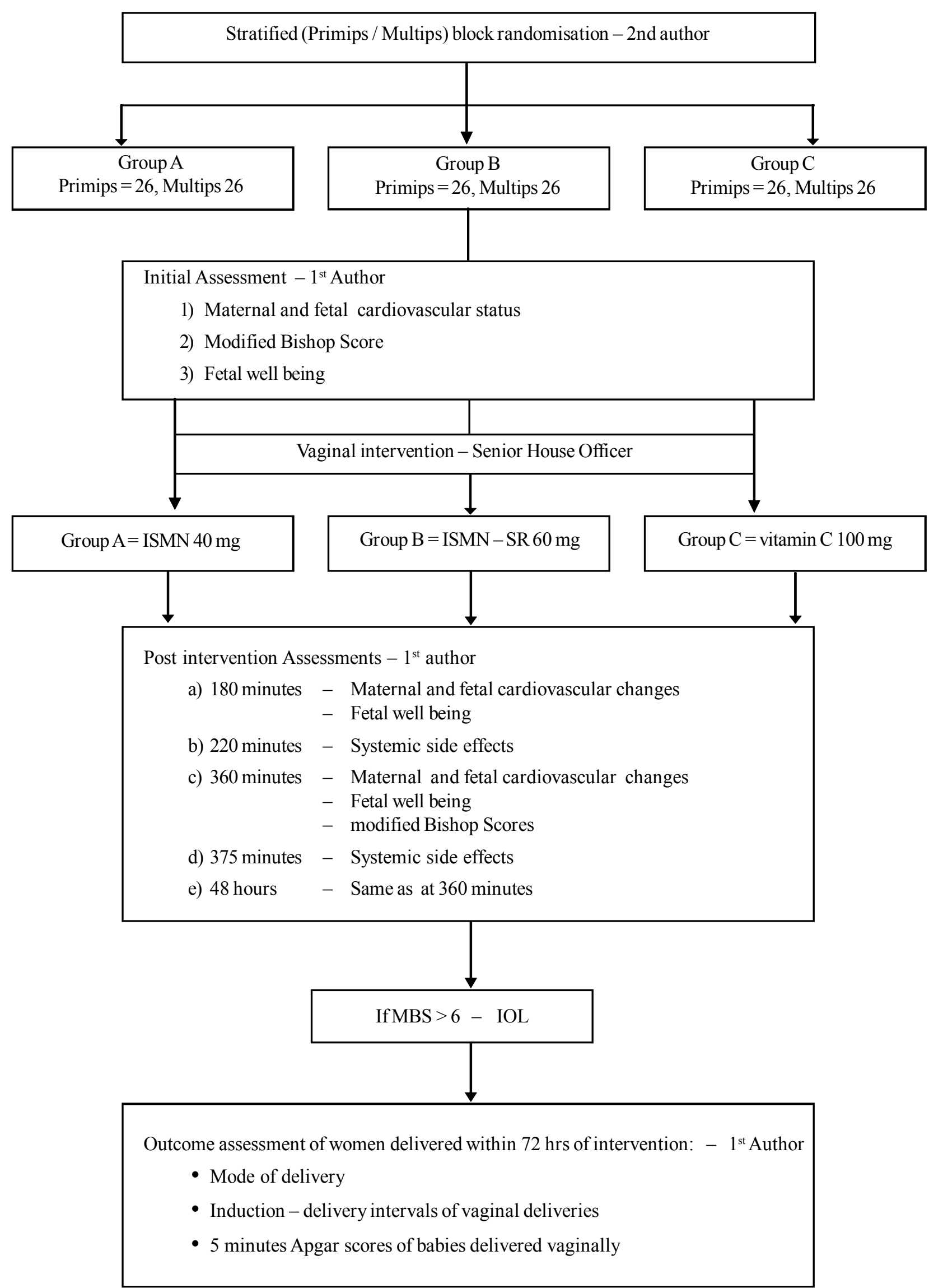


was non reactive it was followed by the fetal acoustic stimulation test (FAST). If the FAST was negative (no fetal movement felt by mother and CTG persisted as non reactive) in any woman, she was excluded from the study and managed according to the clinical guidelines adopted in the unit. The pulseoximeter (N -595 Nellcor), Ireland, the digital blood pressure monitor (Omron Corporation, Japan, corometric cardiotocograph (172 Wipro GE Medical Systems USA), corometric model 146 fetal acoustic stimulator and the logiq 3 pro console ultrasound scanner (Wipro GE Medical Systems USA), were used to monitor the PR, BP and to carry out the CTG, FAST and the umbilical artery RI and PI respectively.

After initial assessment by the first author, the women were handed over to a senior house officer (SHO). The SHO selected in sequence the appropriately numbered, sealed, opaque envelope and its contents were inserted into the posterior fornix of the vagina of each woman.

All the women recruited for the study were given refreshments, four hours after the therapy. All subsequent assessments were carried out by the first author who initially assessed the women and he was blind to the therapy given to the women. The PR, BP, CTG and umbilical artery RI, PI were recorded at 180 minutes and 360 minutes after the intervention. If the CTG persisted to be non reactive even after FAST in any woman, she was removed from the study and an emergency CS arranged.

At 210 minutes and at 360 minutes, all the women were asked to complete a questionnaire regarding the presence of headache, hot flushes, palpitations, dizziness, abdominal pain, pelvic pain and nausea. If any of these symptoms were present, the mothers were requested to describe the intensity of the symptoms based on a visual analogue scale. For statistical assessment of the intensity of these symptoms, each scale was graded from 0 (no symptoms) to 10 (symptoms of maximal intensity). The first author carried out a reassessment of the MBS at 375 minutes after the intervention.

If any woman delivered (vaginally or by CS) within 48 hours after administration of therapy the babies' 5 minute Apgar scores were recorded. All the other remaining women had a repeat assessment 48 hours after the initial therapy. If the CTG was non reactive and the FAST was negative, CS was carried out.

In the women who had cervices which were grossly unfavourable for IOL 48 hours after the initial therapy, cervical ripening was carried out with an intra-cervical Foley catheter according to the clinical guidelines adopted in the unit. The women who had favourable cervices (modified Bishop Scores $>6$ ) had IOL with amniotomy and intravenous oxytocin infusion and their induction delivery interval, mode of delivery and babies' 5 min Apgar scores were recorded if they successfully delivered vaginally.
The outcome measures of the study were PR and BP at 180, 360 minutes and after 48 hours, RI and PI at 180 and 360 minutes and after 48 hours, modified Bishop Scores at 375 minutes, CTG and FAST results, the side effects, the proportion establishing spontaneous labour or becoming favourable for IOL or needing CS within 48 hours of the therapy, and in the women who underwent IOL, mode of delivery, induction delivery interval and the 5 minutes Apgar scores of babies delivered vaginally within 72 hours of the initial therapy.

Analysis of variance was used to compare the means of the continuous variables if the data were normally distributed and the Bonferroni post hoc test if the overall F value showed significant differences between the groups $(p<0.05)$. The Chi Square Test and Fisher's Exact Limits were used to compare the proportions of the dichotomous variables. The statistical package SPSS 14th edition was used.

\section{Results}

By the end of the study period (one year), 156 women had been recruited for the study. Two of the multigravid women were excluded from the analysis because they had pre-labour rupture of membranes within two hours of drug administration. Therefore in this study, 51 women received ISMN $40 \mathrm{mg}$, 52 women received ISMN - SR $60 \mathrm{mg}$ and 51 women received the placebo vitamin C $100 \mathrm{mg}$ vaginally. At the commencement of the study there were no significant differences in parity and mean age, MBS, PR, SBP and DBP, RI and PI among the three treatment groups (Table 1).

There was a significant increase $(p<0.001)$ of mean MBS by $1.3(95 \%$ CI $0.8,1.7)$ in primips and by $1.7(95 \%$ CI $1.3,2.0)$ in multips after 6 hours in the ISMN $40 \mathrm{mg}$ treatment group and no significant increase thereafter. There was a significant increase $(p<0.001)$ of mean MBS by $2.4(95 \%$ CI $1.9,2.7)$ in primips and by $2.3(95 \%$ CI 2.0 , 2.6) in multips after 48 hours in the ISMN SR $-60 \mathrm{mg}$ treatment group. In the vitamin $\mathrm{C}$ treatment group there were no significant changes in the mean MBS even after 48 hours. There were no significant differences in the changes in the MBS between primips and multips (Table 2).

There were no significant changes in maternal DBP and the umbilical artery RI PI in any of the treatment groups. The maternal PR increased by a mean of $6.7-10.2 \mathrm{bpm}$ $(95 \%$ CI $5.0-12.5, p<0.001)$ and the maternal SPB decreased by a mean of $7.3-10 \mathrm{mmHg}(95 \%$ CI $5.5-11.7$, $p<0.001$ ) by 180 minutes and persisted up to 360 minutes after vaginal ISMN therapy with no similar changes observed with the placebo vitamin C (Table 3 ). However, these changes were not of any clinical significance. The side effects reported are given in Table 4 . The intensity of headache was mild and it responded to paracetamol. At 48 hours the maternal PR and SBP had returned to the baseline levels prior to therapy (Table 3 ). 
Table 1. The basic characteristics of subjects $(n=154)$

\begin{tabular}{|c|c|c|c|}
\hline & $\begin{array}{c}I S M N 40 m g \\
\quad n=51 *\end{array}$ & $\begin{array}{c}I S M N-S R 60 m g \\
n=52\end{array}$ & $\begin{array}{l}\text { Vitamin } C \\
n=51^{*}\end{array}$ \\
\hline Number of primips & 26 & 26 & 26 \\
\hline $\begin{array}{l}\text { Mean age of primips - years } \\
(95 \% \mathrm{CI})\end{array}$ & $\begin{array}{c}24.5 \\
(23.2,25.8)\end{array}$ & $\begin{array}{c}25 \\
(23.6,26.4)\end{array}$ & $\begin{array}{c}24.5 \\
(22.9,26.1)\end{array}$ \\
\hline $\begin{array}{l}\text { Mean age of multips - years } \\
(95 \% \mathrm{CI})\end{array}$ & $\begin{array}{c}29.0 \\
(27.2,30.8)\end{array}$ & $\begin{array}{c}29.1 \\
(27.4,30.8)\end{array}$ & $\begin{array}{c}28.6 \\
(26.9,30.3)\end{array}$ \\
\hline $\begin{array}{l}\text { Mean MBS } \\
(95 \% \mathrm{CI})\end{array}$ & $\begin{array}{c}3.45 \\
(3.3-3.7)\end{array}$ & $\begin{array}{c}3.50 \\
(3.3-3.7)\end{array}$ & $\begin{array}{c}3.40 \\
(3.2-3.7)\end{array}$ \\
\hline $\begin{array}{l}\text { Mean pulse rate }-\mathrm{bpm} \\
(95 \% \mathrm{CI})\end{array}$ & $\begin{array}{c}83.1 \\
(80.9-85.3)\end{array}$ & $\begin{array}{c}83.2 \\
(81.6-84.9)\end{array}$ & $\begin{array}{c}82.7 \\
(81.4-83.9)\end{array}$ \\
\hline $\begin{array}{l}\text { Mean SBP }-\mathrm{mmHg} \\
(95 \% \mathrm{CI})\end{array}$ & $\begin{array}{c}117.0 \\
(114-120)\end{array}$ & $\begin{array}{c}118.0 \\
(116-119)\end{array}$ & $\begin{array}{c}118.0 \\
(115-120)\end{array}$ \\
\hline $\begin{array}{l}\text { Mean DBP }-\mathrm{mmHg} \\
(95 \% \mathrm{CI})\end{array}$ & $\begin{array}{c}72.0 \\
(69.3-74.6)\end{array}$ & $\begin{array}{c}71.6 \\
(69.8-73.4)\end{array}$ & $\begin{array}{c}71.8 \\
(69.7-73.9)\end{array}$ \\
\hline $\begin{array}{l}\text { Mean PI } \\
(95 \% \mathrm{CI})\end{array}$ & $\begin{array}{c}0.84 \\
(0.83-0.90)\end{array}$ & $\begin{array}{c}0.87 \\
(0.84-0.89)\end{array}$ & $\begin{array}{c}0.86 \\
(0.82-0.90)\end{array}$ \\
\hline $\begin{array}{l}\text { Mean RI } \\
(95 \% \mathrm{CI})\end{array}$ & $\begin{array}{c}0.57 \\
(0.53-0.58)\end{array}$ & $\begin{array}{c}0.56 \\
(0.54-0.58)\end{array}$ & $\begin{array}{c}0.57 \\
(0.54-0.59)\end{array}$ \\
\hline
\end{tabular}

* One participant from each of these groups was excluded from the study due to pre-labour rupture of membranes.

ISMN - SR ISO-sorbide mononitrate slow releasing form

PI pulsatility index

SBP systolic blood pressure MB modified Bishop Score DB diastolic blood pressure

RI resistance Index $\quad 95 \%$ CI $\quad 95 \%$ confidence Interval

Table 2. Mean changes in modified Bishop Score $(\mathbf{n}=154)$

\begin{tabular}{|c|c|c|c|}
\hline Primips & $\begin{array}{l}I S M N 40 m g \\
\quad(n=26)\end{array}$ & $\begin{array}{c}I S M N-S R 60 m g \\
\quad(n=26)\end{array}$ & $\begin{array}{l}\text { Vitamin } C \\
(n=26)\end{array}$ \\
\hline $\begin{array}{l}\text { Mean change in MBS at } 360 \text { minutes } \\
(95 \% \mathrm{CI})\end{array}$ & $\begin{array}{c}\mathbf{1 . 3} \\
(0.8,1.7) \\
p<0.001\end{array}$ & $\begin{array}{c}\mathbf{0 . 3} \\
(-0.1,0.5)\end{array}$ & $\begin{array}{c}\mathbf{0 . 2} \\
(0.03,0.35)\end{array}$ \\
\hline $\begin{array}{l}\text { Mean change in MBS at } 48 \text { hours } \\
(95 \% \mathrm{CI})\end{array}$ & $\begin{array}{c}\mathbf{1 . 6} \\
(1.2,1.9)\end{array}$ & $\begin{array}{c}\mathbf{2 . 4} \\
(1.9,2.7) \\
p<0.001\end{array}$ & $\begin{array}{c}\mathbf{0 . 5} \\
(-0.08,0.97)\end{array}$ \\
\hline Multips & $(\mathrm{n}=25)^{*}$ & $(n=26)$ & $(\mathrm{n}=25)^{*}$ \\
\hline $\begin{array}{l}\text { Mean change in MBS at } 360 \text { minutes } \\
(95 \% \mathrm{CI})\end{array}$ & $\begin{array}{c}\mathbf{1 . 7} \\
(1.3,2.0) \\
p<0.001\end{array}$ & $\begin{array}{c}\mathbf{0 . 2} \\
(0.07,0.4)\end{array}$ & $\begin{array}{c}\mathbf{0 . 2} \\
(-0.03,0.4)\end{array}$ \\
\hline $\begin{array}{l}\text { Mean change in MBS at } 48 \text { hours } \\
(95 \% \mathrm{CI})\end{array}$ & $\begin{array}{c}1.9 \\
(1.4,2.3)\end{array}$ & $\begin{array}{c}\mathbf{2 . 3} \\
(2.0,2.6) \\
p<0.001\end{array}$ & $\begin{array}{c}\mathbf{0 . 9} \\
(0.4,1.31)\end{array}$ \\
\hline
\end{tabular}

* One participant from each of these groups was excluded from the study due to pre-labour rupture of membranes.

ISMN - SR iso-sorbide mononitrate slow release form $\quad$ MBS modified Bishop Score $\quad 95 \%$ CI $95 \%$ confidence interval 
Table 3. Haemodynamic changes at 180 mins, 360 mins and 48 hours $(n=154)$

\begin{tabular}{|c|c|c|c|c|}
\hline & $\begin{array}{l}I S M N 40 m g \\
\quad(n=51)^{*}\end{array}$ & $\begin{array}{c}I S M N-S R 60 m g \\
(n=52)\end{array}$ & $\begin{array}{l}\text { Vitamin } C \\
(n=51)^{*}\end{array}$ & $p$ value \\
\hline \multicolumn{5}{|c|}{ Mean increase in PR (bpm) } \\
\hline $\begin{array}{l}\text { At } 180 \text { minutes } \\
(95 \% \mathrm{CI})\end{array}$ & $\begin{array}{c}10.2 \\
(7.9-12.5)\end{array}$ & $\begin{array}{c}\mathbf{6 . 7} \\
(5.0-8.4)\end{array}$ & $\begin{array}{c}\mathbf{0 . 4 5} \\
(-2.3-1.4)\end{array}$ & $<0.001$ \\
\hline $\begin{array}{l}\text { At } 360 \text { minutes } \\
(95 \% \mathrm{CI})\end{array}$ & $\begin{array}{c}\mathbf{8 . 9} \\
(6.6-11.3)\end{array}$ & $\begin{array}{c}7.8 \\
(6.0-9.6)\end{array}$ & $\begin{array}{c}\mathbf{0 . 4 5} \\
(-2.2-1.3)\end{array}$ & $<0.001$ \\
\hline $\begin{array}{l}\text { At } 48 \text { hours } \\
(95 \% \mathrm{CI})\end{array}$ & $\begin{array}{c}\mathbf{0 . 0 8} \\
(-1.6-1.7)\end{array}$ & $\begin{array}{c}\mathbf{0 . 1 2} \\
(-1.9-1.7)\end{array}$ & $\begin{array}{c}\mathbf{0 . 7 5} \\
(-1.2-2.7)\end{array}$ & NS \\
\hline \multicolumn{5}{|c|}{ Mean reduction in SBP $(\mathrm{mmHg})$} \\
\hline $\begin{array}{l}\text { At } 180 \text { minutes } \\
(95 \% \mathrm{CI})\end{array}$ & $\begin{array}{c}\mathbf{9 . 8} \\
(8.2-11.7)\end{array}$ & $\begin{array}{c}10 \\
(8.6-11.4)\end{array}$ & $\begin{array}{c}\mathbf{0 . 5} \\
(1.3-2.3)\end{array}$ & $<0.001$ \\
\hline $\begin{array}{l}\text { At } 360 \text { minutes } \\
(95 \% \mathrm{CI})\end{array}$ & $\begin{array}{c}7.3 \\
(4.7-9.8)\end{array}$ & $\begin{array}{c}7.8 \\
(5.5-9.2)\end{array}$ & $\begin{array}{c}\mathbf{0 . 6} \\
(-2.4-1.2)\end{array}$ & $<0.001$ \\
\hline $\begin{array}{l}\text { At } 48 \text { hours } \\
(95 \% \mathrm{CI})\end{array}$ & $\begin{array}{c}1.9 \\
(-6.66-4.3)\end{array}$ & $\begin{array}{c}1.2 \\
(-1.4-3.8)\end{array}$ & $\begin{array}{c}\mathbf{2 . 9} \\
(3.7-5.5)\end{array}$ & NS \\
\hline \multicolumn{5}{|c|}{ Mean reduction in DBP $(\mathrm{mmHg})$} \\
\hline $\begin{array}{l}\text { At } 180 \text { minutes } \\
(95 \% \mathrm{CI})\end{array}$ & $\begin{array}{c}2.2 \\
(0.45-3.9)\end{array}$ & $\begin{array}{c}1.3 \\
(0.4-2.8)\end{array}$ & $\begin{array}{c}\mathbf{0 . 2 5} \\
(-1.4-1.9)\end{array}$ & NS \\
\hline $\begin{array}{l}\text { At } 360 \text { minutes } \\
(95 \% \mathrm{CI})\end{array}$ & $\begin{array}{c}1.5 \\
(-0.4-3.3)\end{array}$ & $\begin{array}{c}\mathbf{0 . 5} \\
(-1.4-2.4)\end{array}$ & $\begin{array}{c}\mathbf{- 0 . 2 5} \\
(-1.9-1.4)\end{array}$ & NS \\
\hline $\begin{array}{l}\text { At } 48 \text { hours } \\
(95 \% \mathrm{CI})\end{array}$ & $\begin{array}{c}-\mathbf{2 . 2} \\
(-2.6-2.1)\end{array}$ & $\begin{array}{c}\mathbf{- 2 . 1} \\
(-4.3-0.2)\end{array}$ & $\begin{array}{c}-4.1 \\
(-6.3-1.9)\end{array}$ & NS \\
\hline \multicolumn{5}{|c|}{ Mean change in RI } \\
\hline $\begin{array}{l}\text { At } 180 \text { minutes } \\
(95 \% \mathrm{CI})\end{array}$ & $\begin{array}{c}\mathbf{- 0 . 0 1 5} \\
(-0.04-0.01)\end{array}$ & $\begin{array}{c}\mathbf{0 . 0 0 2 1} \\
(0.016-0.02)\end{array}$ & $\begin{array}{c}\mathbf{0 . 0 0 4 5} \\
(.022-0.014)\end{array}$ & NS \\
\hline $\begin{array}{l}\text { At } 360 \text { minutes } \\
(95 \% \mathrm{CI})\end{array}$ & $\begin{array}{c}\mathbf{0 . 0 1} \\
(-0.04-0.15)\end{array}$ & $\begin{array}{c}\mathbf{0 . 0 2} \\
(-0.02-0.016)\end{array}$ & $\begin{array}{c}\mathbf{0 . 0 1} \\
(-0.02-0.02)\end{array}$ & NS \\
\hline $\begin{array}{l}\text { At } 48 \text { hours } \\
(95 \% \mathrm{CI})\end{array}$ & $\begin{array}{c}\mathbf{0 . 0 7} \\
(-0.03-.023)\end{array}$ & $\begin{array}{c}\mathbf{0 . 0 1} \\
(-0.02-0.02)\end{array}$ & $\begin{array}{c}\mathbf{0 . 0 4} \\
(-0.03-0.02)\end{array}$ & NS \\
\hline \multicolumn{5}{|c|}{ Mean change in PI } \\
\hline $\begin{array}{l}\text { At } 180 \text { minutes } \\
(95 \% \mathrm{CI})\end{array}$ & $\begin{array}{c}\mathbf{0 . 0 1} \\
(-0.06-0.04)\end{array}$ & $\begin{array}{c}\mathbf{0 . 0 0 5} \\
(-0.02-0.03)\end{array}$ & $\begin{array}{c}\mathbf{0 . 0 0 8} \\
(-0.04-0.03)\end{array}$ & NS \\
\hline $\begin{array}{l}\text { At } 360 \text { minutes } \\
(95 \% \mathrm{CI})\end{array}$ & $\begin{array}{c}\mathbf{0 . 0 1} \\
(-0.03-0.05)\end{array}$ & $\begin{array}{c}\mathbf{0 . 0 0 5} \\
(-0.03-0.02)\end{array}$ & $\begin{array}{c}\mathbf{0 . 0 1} \\
(-0.05-0.025)\end{array}$ & NS \\
\hline $\begin{array}{l}\text { At } 48 \text { hours } \\
(95 \% \text { CI })\end{array}$ & $\begin{array}{c}\mathbf{0 . 0 6} \\
(-0.05-0.06)\end{array}$ & $\begin{array}{c}\mathbf{0 . 0 2} \\
(-0.06-0.02)\end{array}$ & $\begin{array}{c}\mathbf{0 . 0 1} \\
(-0.07-0.04)\end{array}$ & NS \\
\hline
\end{tabular}

*One participant from each of these groups was excluded from the study due to pre-labour rupture of membranes.

$\begin{array}{llll}\text { ISMN }- \text { SR } \quad \text { iso-sorbide mononitrate slow releasing form } & \text { NS } & \text { not significant } \\ & & \text { PI } & \text { pulsatility index } \\ \text { SBP } & \text { systolic blood pressure } & \text { DBP } & \text { diastolic blood pressure } \\ \text { bpm } & \text { beats per minute } & \text { RI } & \text { resistance index } \\ 95 \% \text { CI } & 95 \% \text { confidence interval } & \text { MBS } & \text { modified Bishop Score }\end{array}$


Table 4. Number of women with side effects in the six hour period after the intervention $(n=154)$

\begin{tabular}{|c|c|c|c|c|c|c|c|c|}
\hline & \multicolumn{4}{|c|}{$\begin{array}{l}\text { Side effects } \\
\text { ISMN }\end{array}$} & \multicolumn{3}{|c|}{$\begin{array}{c}\text { Intensity of side effects } \\
\text { ISMN }\end{array}$} & \multirow[b]{2}{*}{$\begin{array}{c}P \\
\text { value }\end{array}$} \\
\hline & $\begin{array}{c}I S M N \\
40 m g \\
n=51^{*}\end{array}$ & $\begin{array}{c}-S R \\
60 m g \\
n=52\end{array}$ & $\begin{array}{c}\text { Vitamin } \\
\qquad \\
n=51^{*}\end{array}$ & $\begin{array}{c}P \\
\text { value }\end{array}$ & $\begin{array}{l}I S M N \\
40 m g \\
n=51^{*}\end{array}$ & $\begin{array}{c}-S R \\
60 m g \\
n=52\end{array}$ & $\begin{array}{c}\text { Vitamin } \\
\qquad \\
n=51^{*}\end{array}$ & \\
\hline \multicolumn{9}{|l|}{ Headache } \\
\hline 210 minutes & 26 & 19 & 1 & $<0.01$ & 3.2 & 2.38 & 1.1 & $<0.01$ \\
\hline 360 minutes & 18 & 10 & 1 & & 2.08 & 1.4 & 1.02 & \\
\hline \multicolumn{9}{|c|}{ Nausea / vomiting } \\
\hline 210 minutes & 6 & 4 & 0 & $<0.01$ & 1.45 & 1.25 & 1.1 & $<0.01$ \\
\hline 360 minutes & 3 & 0 & 0.00 & & 1.1 & 1 & 1 & \\
\hline \multicolumn{9}{|l|}{ Pelvic pain } \\
\hline 210 minutes & 5 & 1 & 3 & NS & 1.35 & 1.1 & 1.1 & NS \\
\hline 360 minutes & 4 & 2 & 0 & & 1.22 & 1.2 & 1.02 & \\
\hline \multicolumn{9}{|l|}{ Abdominal pain } \\
\hline 210 minutes & 7 & 2 & 1 & NS & 1.24 & 1.06 & 1.02 & NS \\
\hline 360 minutes & 4 & 2 & 2 & & 1.18 & 1.1 & 1.08 & \\
\hline \multicolumn{9}{|l|}{ Dizziness } \\
\hline 210 minutes & 6 & 2 & 1 & NS & 1.27 & 1.1 & 1 & NS \\
\hline 360 minutes & 5 & 1 & 0 & & 1.2 & 1.02 & 1 & \\
\hline \multicolumn{9}{|l|}{ Palpitations } \\
\hline 210 minutes & 1 & 0 & 0 & NS & 1.06 & 1 & 1 & NS \\
\hline 360 minutes & 3 & 1 & 0 & & 1.14 & 1.02 & 1 & \\
\hline \multicolumn{9}{|l|}{ Hot flushes } \\
\hline 210 minutes & 2 & 1 & 2 & NS & 1.08 & 1.02 & 1.02 & NS \\
\hline 360 minutes & 0 & 0 & 1 & & 1 & 1 & 1 & \\
\hline
\end{tabular}

*One participant from each of these groups was excluded from the study due to pre-labour rupture of membranes.

$\begin{array}{ll}\text { ISMN - SR } & \text { Iso-sorbide mononitrate slow release form } \\ \text { MBS } & \text { modified Bishop Score } \\ 95 \% \text { CI } & 95 \% \text { confidence interval } \\ \text { mins } & \text { minutes } \\ \text { NS } & \text { not significant }\end{array}$

Greater proportions of primips ( $42 \%$ with ISMN-SR $60 \mathrm{mg}$ and $31 \%$ with ISMN $40 \mathrm{mg}, p<0.05$ ) were favourable for IOL after 48 hours in comparison with the controls (7.6\%). Greater proportions of multips (46\% with ISMN SR $60 \mathrm{mg}$ and $40 \%$ with ISMN $40 \mathrm{mg}, p<0.05)$ were favourable for IOL after 48 hours in comparison with the controls (16\%). Within the first 48 hours of the intervention there were no significant differences in the proportions establishing spontaneous labour or requiring emergency CS among the three groups and between primips and multips. Furthermore there were no significant differences between primips and multips in the proportions becoming favourable for IOL after ISMN therapy (Tables 5 and 6).

In the women who underwent IOL, there was no significant difference in emergency CS rates due to fetal distress or failed IOL, or in the mean induction-delivery intervals and mean 5 minutes Apgar scores of babies delivered vaginally within 72 hours of the interventions among the three groups and between primips and multips (Table 7). 
Table 5. Outcomes 48 hours after the intervention in the primips $(n=78)$

\begin{tabular}{|c|c|c|c|}
\hline & $\begin{array}{l}I S M N 40 m g \\
\quad(n=26)\end{array}$ & $\begin{array}{c}I S M N-S R 60 m g \\
(n=26)\end{array}$ & $\begin{array}{l}\text { Vitamin } C \\
(n=26)\end{array}$ \\
\hline Spontaneous onset of labour within 48 hours & $\begin{array}{c}7 \\
(27 \%)\end{array}$ & $\begin{array}{c}6 \\
(23 \%)\end{array}$ & $\begin{array}{c}8 \\
(31 \%)\end{array}$ \\
\hline Emergency caesarean section within 48 hours & 0 & 0 & $\begin{array}{c}1 \\
(3.8 \%)\end{array}$ \\
\hline Not delivered at 48 hours & $\begin{array}{c}19 \\
(73 \%)\end{array}$ & $\begin{array}{c}20 \\
(77 \%)\end{array}$ & $\begin{array}{c}17 \\
(65 \%)\end{array}$ \\
\hline Favourable for IOL after 48 hours & $\begin{array}{c}8 \\
(31 \%) \\
p<0.05\end{array}$ & $\begin{array}{c}11 \\
(42 \%) \\
p<0.05\end{array}$ & $\begin{array}{c}2 \\
(7.6 \%)\end{array}$ \\
\hline Not favourable for IOL after 48 hours & $\begin{array}{c}11 \\
(42 \%) \\
p<0.05\end{array}$ & $\begin{array}{c}9 \\
(35 \%) \\
p<0.05\end{array}$ & $\begin{array}{c}15 \\
(58 \%)\end{array}$ \\
\hline
\end{tabular}

ISMN iso-sorbide mononitrate

ISMN - SR iso-sorbide mononitrate slow release form

IOL induction of labour

Table 6. Outcomes 48 hours after the intervention in the multips $(n=76)$

\begin{tabular}{|c|c|c|c|}
\hline & $\begin{array}{l}I S M N 40 m g \\
(n=25)^{*}\end{array}$ & $\begin{array}{c}I S M N-S R 60 m g \\
(n=26)\end{array}$ & $\begin{array}{l}\text { Vitamin } C \\
(n=25)^{*}\end{array}$ \\
\hline Spontaneous onset of labour within 48 hours & $\begin{array}{c}9 \\
(36 \%)\end{array}$ & $\begin{array}{c}6 \\
(23 \%)\end{array}$ & $\begin{array}{c}9 \\
(36 \%)\end{array}$ \\
\hline Emergency caesarean section within 48 hours & $\begin{array}{c}1 \\
(4 \%)\end{array}$ & $\begin{array}{c}1 \\
(3.8 \%)\end{array}$ & 0 \\
\hline Not delivered at 48 hours & $\begin{array}{c}15 \\
(60 \%)\end{array}$ & $\begin{array}{c}19 \\
(73 \%)\end{array}$ & $\begin{array}{c}16 \\
(64 \%)\end{array}$ \\
\hline Favourable for IOL after 48 hours & $\begin{array}{c}10 \\
(40 \%) \\
p<0.05\end{array}$ & $\begin{array}{c}12 \\
(46 \%) \\
p<0.05\end{array}$ & $\begin{array}{c}4 \\
(16 \%)\end{array}$ \\
\hline Not favourable for IOL after 48 hours & $\begin{array}{c}5 \\
(20 \%) \\
p<0.05\end{array}$ & $\begin{array}{c}7 \\
(27 \%) \\
p<0.05\end{array}$ & $\begin{array}{l}12 \\
(48 \%)\end{array}$ \\
\hline
\end{tabular}

*One participant from each of these groups was excluded from the study due to pre-labour rupture of membranes

ISMN- $\quad$ iso-sorbide mononitrate

ISMN - SR iso-sorbide mononitrate slow release form

IOL induction of labour 
Table 7. Outcome in the women who underwent induction of labour $(n=47)$

\begin{tabular}{|c|c|c|c|}
\hline & $\begin{array}{l}I S M N 40 m g \\
(n=18) *\end{array}$ & $\begin{array}{c}I S M N-S R 60 m g \\
(n=23)\end{array}$ & $\begin{array}{c}\text { Vitamin } C \\
(n=6) *\end{array}$ \\
\hline $\begin{array}{l}\text { Mean I/D interval in primips } \\
\text { undergoing IOL after } 48 \text { hours }- \text { minutes } \\
(95 \% \mathrm{CI})\end{array}$ & $\begin{array}{c}\mathrm{n}=8 \\
317.5 \\
(276-358)\end{array}$ & $\begin{array}{c}\mathrm{n}=11 \\
329.7 \\
(282-377) \\
p-\mathrm{NS}\end{array}$ & $\begin{array}{c}\mathrm{n}=2 \\
342.1 \\
(282-402)\end{array}$ \\
\hline $\begin{array}{l}\text { Mean I/D interval in multips } \\
\text { undergoing IOL after } 48 \text { hours - minutes } \\
(95 \% \mathrm{CI})\end{array}$ & $\begin{array}{c}\mathrm{n}=10 \\
277 \\
(203.5-351.2)\end{array}$ & $\begin{array}{c}\mathrm{n}=12 \\
308 \\
(260-356) \\
p-\mathrm{NS}\end{array}$ & $\begin{array}{c}n=4 \\
302 \\
(263-340.5)\end{array}$ \\
\hline $\begin{array}{l}\text { Intrapartum emergency CS for failed IOL } \\
\text { or fetal distress in primips }\end{array}$ & $\mathrm{n}=2$ & $\mathrm{n}=3$ & $\mathrm{n}=1$ \\
\hline $\begin{array}{l}\text { Intrapartum emergency CS for failed IOL } \\
\text { or fetal distress in multips }\end{array}$ & $\mathrm{n}=0$ & $\mathrm{n}=1$ & $\mathrm{n}=1$ \\
\hline $\begin{array}{l}\text { Mean } 5 \text { min Apgar score of babies delivered } \\
\text { within } 72 \text { hours of the intervention } \\
(95 \% \mathrm{CI})\end{array}$ & $\begin{array}{c}n=51 \\
9.2 \\
(9.04,9.36)\end{array}$ & $\begin{array}{c}\mathrm{n}=52 \\
9.9 \\
(9.82,9.98)\end{array}$ & $\begin{array}{c}\mathrm{n}=51 \\
\quad 9.4 \\
(9.24,9.56)\end{array}$ \\
\hline
\end{tabular}

I/ D Interval induction delivery Interval

IOL induction of labour

CS caesarean section

95\% CI $\quad 95 \%$ confidence interval

NS not significant

\section{Discussion}

This trial provides further evidence that in comparison with vitamin $\mathrm{C}$ a placebo, vaginal administration of the $\mathrm{NO}$ donor ISMN results in greater ripening of the cervix in post dated pregnancies. Due to practical problems, the effects of the vaginal ISMN could be evaluated only up to 6 hours after the intervention on the first day. Therefore any effects occurring after 6 hours and up to 48 hours (the time of the next evaluation) would not have been detected in the current study. For example if a reduction of DBP occurred after 6 hours, especially in the group of women administered ISMN - SR $60 \mathrm{mg}$, it would have been missed.

A study carried out in Norway demonstrated a mild but significant $(p<0.01)$ increase in maternal. PR and a mild but significant decrease of both SBP $(p<0.001)$ and DBP ( $p<0.0001), 180$ minutes after vaginal ISMN $40 \mathrm{mg}$. However, none of the women in that study required medical treatment [19]. In the current study, although a mild increase of maternal PR $(p<0.001)$ was noted in both ISMN $40 \mathrm{mg}$ and ISMN - SR $60 \mathrm{mg}$ groups, there was no significant reporting of palpitations by these women.
Although a mild headache was reported by $51 \%$ of women in the ISMN $40 \mathrm{mg}$ group and $37 \%$ of women in the ISMN - SR $60 \mathrm{mg}$ group, paracetamol was adequate to relieve their discomfort and no other clinically significant adverse effects were reported in the current study. As seen in the Norwegian study in the current study too there was no evidence of any adverse effects on the fetus detected by CTG and umbilical artery Doppler RI and PI [19].

Although ISMN $40 \mathrm{mg}$ led to significant ripening of the cervix in 6 hours, the greater degree of cervical ripening after 48 hours and the larger proportion of women becoming favourable for IOL after 48 hours, suggests that therapy with $60 \mathrm{mg}$ of the sustained release form ISMN - SR is a better agent for pre-induction ripening of cervix. There were no significant differences in the change in MBS after ISMN therapy between primips and multips and the proportion of primips and multips becoming favourable for IOL after 48 hours of ISMN therapy. Similarly in the women whose cervices were favourable for IOL at 48 hours and therefore underwent IOL, there was no significant difference in the mean induction delivery intervals between primips and multips. 
The optimum dose, formulation and frequency of administration, and the value of repeated doses of vaginal ISMN, needs to be established. The feasibility and the acceptability of outpatient self medication with vaginal ISMN too needs further study.

\section{Conclusions}

When compared with the placebo vitamin C $100 \mathrm{mg}$, vaginal ISMN $40 \mathrm{mg}$ and ISMN - SR $60 \mathrm{mg}$ lead to significantly greater cervical ripening after 6 hours and 48 hours respectively. Therefore vaginal ISMN leads to more women becoming favourable for IOL. Vaginal ISMN does not affect placental blood flow but causes headaches and clinically insignificant maternal haemodynamic changes.

\section{References}

1. National Institute for Clinical Excellence. Inherited Clinical Guideline - Induction of Labour 2008, accessed 27 July 2010 available from URL: http:// guidance. nice.org.uk

2. Adeniji OA, Oladokun A, Olayemio O, et al. Pre induction cervical ripening: trans cervical Foley catheter versus intra vaginal misoprostol. Journal of Obstetrics and Gynaecology 2005; 25: 134-9.

3. Abramovici D, Goldwasser S, Bill CM, Mercer BM, Goldwasser R, Sibai MB. A randomized comparison of oral misoprostol versus foley catheter and oxytocin for induction of labour at term. American Journal of Obstetrics and Gynaecology 1999; 181: 1108-12.

4. Hales KA, Rayburn WF, Turnbull GL, Christensen HD, Patatanian E. Double-blind comparison of intracervical and intravaginal prostaglandin E2 for cervical ripening and induction of labour. American Journal of Obstetrics and Gynaecology 1994; 171: 1087-91.

5. Ramsey PS, Meyer L, Walker BA, Harris D, Ogburn PL. Jr, Heise RH, Ranin KD. Cardiotocographic abnormalities associated with dinoprostone and misoprostol cervical ripening. Obstetrics and Gynaecology 2005; 105: 85-90.

6. Maymon R, Shulmon A, Pomaranz M, Holtzinger M, Haimovich L, Bahary C. Uterine rupture at term pregnancy with the use of intravaginal prostoglandin E2 gel for induction of labour. American Journal of Obstetrics and Gynaecology 1991; 165: 368-70.

7. Osman I, MacKenzie F, Norrie J, Murry HM, Greer IA, Norman JE. The "PRIMP" study: a randomized comparison of prostaglandin E2 gel with the nitric oxide donor isosorbide mononitrate for cervical ripening before the induction of labour at term. American Journal of Obstetrics and Gynaecology 2006; 194: 1012 -21.

8. Hofmyer GS, Gulmezoglu AM. Vaginal misoprostol for cervical ripening and induction of labour. Cochrane Database of Systematic Reviews 2001; 3: CD 000941.

9. Chwalisz K, Garfield RE. Nitric oxide as the final mediator of cervical ripening. Human Reproduction 1998; 13: 245-52.

10. Vaisanen-Tommiska M, Nuutila M, Aittomaki K, Hiilesmaa $\mathrm{V}$, Ylikorkala O. Nitric oxide metabolites in cervical fluid during pregnancy: further evidence for the role of cervical nitric oxide in cervical ripening. American Journal of Obstetrics and Gynaecology 2003; 188: 779-85.

11. Sennstrom MKB, Brauner A, Lu Y, Granstrom LNM, Malmstrom Al, Ekman GE. Interleukin-8 is a mediator of the final cervical ripening in humans. European Journal of Obstetrics Gynecology and Reproductive Biology 1997; 74: 89-92.

12. Chwalisz K, Benson M, Scholz P, Daum J, Beier HM, Hegelehartung C. Cervical ripening with the cytokines interleukins-8, interleukins-1 $\beta$ and tumor necrosis factor $\alpha$ in guinea pigs. Human Reproduction 1994; 9: 29-35.

13. British Medical Association and Royal Pharmaceutical Society of Great Britain. British National Formulary 2008; 55: 110 -1.

14. Bates CD, Nicoll AE, Mullen AB, Mackenzie F, Thomson AJ, Norman JE. Serum profile of isosorbide mononitrate after vaginal administration in the third trimester. British Journal of Obstetrics and Gynaecology 2003; 110: 64-7.

15. Free Medical Dictionary. Accessed 31 May 2010 available from URL: http:// medical-dictionary.thefreedictionary.com/ Elantan.

16. Bulletic C, de Ziegler D, Flamigni C, et al. Targeted drug delivery in gynaecology: the first uterine pass mechanism. Human Reproduction 1997; 12: 1073-9.

17. Nicoll AE, Mackenzie F, Greer IA, Norman JE. Vaginal application of the nitric oxide donor isosorbide mononitrate for preinduction cervical ripening: a randomized controlled trials to determine effects on maternal and fetal haemodynamics. American Journal of Obstetrics and Gynaecology 2001; 184: 958-64. Comment and author reply in American Journal of Obstetrics and Gynaecology 2002; 186: $593-4$.

18. Rameez MFM, Goonewardene IMR. Nitric oxide donor isosorbide mononitrate for pre induction cervical ripening at 41 weeks' gestation: a randomized controlled trial. The Journal of Obstetrics and Gynaecology Research 2007; 33: 452-6.

19. Ekerhovd E, Bullarbo M, Andersh B, Norstrom A. Vaginal administration of nitric oxide donor isosorbide mononitrate for cervical ripening at term: a randomized control study. American Journal of Obstetrics and Gynaecology 2003; 189: $1692-7$.

20. Bullarbo M, Orrskog ME, Andersch B, Granstro L, Norsrom A, Ekerhovd E. Outpatient vaginal administration of the nitric oxide donor isosorbide mononitrate for cervical ripening and labour induction post-term; a randomized controlled study. American Journal of Obstetrics and Gynaecology 2007; 196: 50. el -5.

21. Bollapragada SS, Mackenzie F, Norrie JD, Eddana O, Petrou S, Reid M, Norman JE. Randomized placebo-controlled trial of out patient (at home) cervical ripening with isosorbide mononitrate (IMN) prior to induction of labour - clinical trial with analyses of efficacy and acceptability. The IMOP study. British Journal of Obstetrics and Gynaecology 2009; 116: $1185-95$.

22. Biswas A, Arulkumaran S. Induction of Labour. In: Arulkumaran S, Ratnam SS, Basker Rao K (eds). The Management of Labour. Vol 14, Madras, Orient Longman Ltd, 1996; 213-27. 